\title{
Laryngopharyngeal Reflux in Children with Chronic Otitis Media with Effusion
}

\author{
Anna Górecka-Tuteja, ${ }^{1}$ Izabela Jastrzębska, ${ }^{2 *}$ Jacek Składzień, ${ }^{3}$ and Krzysztof Fyderek ${ }^{2}$ \\ ${ }^{\prime}$ Department of Otolaryngology, Rydygier Memorial Specialistic Hospital, Cracow, Poland; and Departments of ${ }^{2}$ Pediatrics, Gastroenterology and \\ Nutrition, and ${ }^{3}$ Otolaryngology, Collegium Medicum Jagiellonian University, Cracow, Poland
}

\section{Background/Aims}

To evaluate the characteristic properties of laryngopharyngeal reflux (LPR) and gastroesophageal reflux (GER) in children with otitis media with effusion (OME) using 24-hour multichannel intraluminal impedance combined with dual-probe (pharyngeal and esophageal) pH-metry.

\section{Methods}

Children aged 7-10 years of age with OME underwent 24-hour multichannel intraluminal impedance pH-metry. The upper pH sensor was situated $1 \mathrm{~cm}$ above the upper esophageal sphincter, and the lower $\mathrm{pH}$ sensor was placed 3-5 cm above the lower esophageal sphincter. Parents were asked to complete the gastroesophageal reflux assessment of symptoms in a pediatrics questionnaire.

\section{Results}

Twenty-eight children were enrolled; LPR was detected in $19(67.9 \%)$ children. The criteria of the LPR diagnosis was the presence of at least one supraesophageal episode with a $\mathrm{pH}<5.0$ and a change in the $\mathrm{pH}$ value measured from the initial level at the upper sensor of $>0.2$. In total, 64 episodes were observed. Assessment of all LPR episodes showed the presence of 246 episodes in the entire study. A considerable predominance of weakly acidic episodes (87.8\%) was noted; there were $6.5 \%$ acidic episodes, and weakly alkaline episodes reached 5.7\%. Pathological GER was noted in 10 (35.7\%) subjects. Acid GER was detected in 8 children, 2 of whom demonstrated non-acidic reflux. In the LPR-negative patients, no pathological GER was confirmed with the exception of a single case of non-acidic reflux.

\section{Conclusions}

LPR was frequently noted in the group of children with OME, and it might be an important risk factor in this common disease.

\section{(J Neurogastroenterol Motil 2016;22:452-458)}

\section{Key Words}

Child; Electric impedance; Esophageal pH monitoring; Laryngopharyngeal reflux; Otitis media with effusion

Received: January 21, 2016 Revised: April 17, 2016 Accepted: May 3, 2016

(a) This is an Open Access article distributed under the terms of the Creative Commons Attribution Non-Commercial License (http://creativecommons. org/licenses/by-nc/4.0) which permits unrestricted non-commercial use, distribution, and reproduction in any medium, provided the original work is properly cited.

*Correspondence: Izabela Jastrzębska, MD

Department of Pediatrics, Gastroenterology and Nutrition, Collegium Medicum Jagiellonian University, Cracow, Poland, ul. Wielicka 265, 30-663 Cracow, Poland

Tel: +48-504279982, Fax: +48-126574012,E-mail: izabela.1.jastrzebska@uj.edu.pl 


\section{Introduction}

Otitis media with effusion (OME) is defined as conductive hearing loss with the presence of fluid within the middle ear with no symptoms or signs of acute inflammation and without perforation of the tympanic membrane. It is the most common cause of acquired hearing loss in children. ${ }^{1}$ It occurs in approximately $15 \%$ of children 2 to 7 years of age. ${ }^{2,3}$ Chronic OME lasts for more than 3 months.

The etiology of chronic OME is multifactorial, yet the main culprit seems to be the dysfunction and impaired patency of the Eustachian tube. ${ }^{1}$ One of the factors taken into consideration is laryngopharyngeal reflux (LPR). ${ }^{1}$

LPR is defined as a bolus movement from the stomach above the upper esophageal sphincter (UES). LPR can lead to upper respiratory tract pathologies via 3 mechanisms. The most important mechanism is a direct noxious effect of acid gastric contents on the mucosa, causing its swelling, mucus hypersecretion, ciliary dyskinesia, and stimulation of the secretion of inflammatory mediators. Another mechanism consists of triggering a vagus nerve response supported by excessive vagal reactivity, which is observed in patients with LPR compared with healthy people. The third hypothesis postulates an association between Helicobacter pylori infection and OME; this bacteria has been identified in aspirates from the middle ear. $^{1,4,5}$

According to the Montreal consensus criteria, relationships between LPR and reflux laryngitis, reflux asthma syndrome, reflux cough syndrome, and reflux teeth erosion have been confirmed in adults. ${ }^{6}$ In children, these associations have not been proven yet. ${ }^{7}$ Other disorders, such as pharyngitis, sinusitis, recurrent otitis media, and pulmonary fibrosis, may be related to LPR, but these associations lacks adequate evidence. ${ }^{6}$

The main objective of the study was to characterize LPR and gastroesophageal reflux (GER) in children with OME by employing esophageal multichannel intraluminal impedance (MII) combined with dual-probe (pharyngo-esophageal) $\mathrm{pH}$-metry. The secondary objective was to compare LPR criteria developed specifically for that study with the commonly used criteria of LPR.

\section{Materials and Methods}

Twenty-eight children between 7 and 10 years of age with chronic OME who were consecutively referred to the Outpatient Clinic of Otolaryngology Department of Rydygier Memorial
Hospital in Cracow between 2008 and 2011 were enrolled. The patients were recruited for the study upon the approval of the Jagiellonian University Collegium Medicum Bioethics Committee No $\mathrm{KBET} / 13 / \mathrm{B} / 2008$.

Children with a significantly deviated nasal septum, nasal polyps, palato-pharyngeal sphincter dysfunction, coagulopathy, cystic fibrosis, cranio-facial defects, or without parental/legal guardian informed consent were excluded from the study. The mean age of the children was 8 years and 3 months (range 7-10 years). There were 17 boys (60.7\%) and 11 girls (39.3\%).

The diagnosis of OME was established on the basis of the otorhinolaryngological examination, including otomicroscopic examination and audiological tests: $435 \mathrm{~Hz}$ tuning-fork tests and tympanometric and audiometric studies. Tympanometry is an indirect measurement of the compliance and impedance of the tympanic membrane and ossicles of the middle ear. The results are presented in graphic form. Tympanogram type $\mathrm{A}$ is the norm. Tympanogram types $\mathrm{B}$ or $\mathrm{C} 2$ indicate the presence of effusion in the middle ear. With audiometry, we estimated the air-bone gap. The air bone gap is the difference between the hearing threshold for bone conduction and air conduction, and it occurs in conductive hearing loss. The mean air bone gap was calculated for 500, 1000, 2000, and 4000 Hz.

The gastroesophageal symptoms were assessed with a pediatrics questionnaire (GASP-Q) for children 5 to 18 years of age.

Subsequently, all the children underwent 24-hour dual-probe $\mathrm{pH}$ monitoring with $\mathrm{MII}(\mathrm{MII} / \mathrm{pH})$ during a one-day hospitalization at the Department of Pediatrics, Gastroenterology and Nutrition, University Children's Hospital of Cracow. Polyvinyl, soft, 2.3 mm impedance catheters (Sleuth System; Sandhill Scientific Inc, Highlands Ranch, CO, USA) of 2 lengths (ZPI-S62C23E and ZAI-S62C28E) were used in this study. The probe contained 6 MII electrode pairs and 2 antimony $\mathrm{pH}$ electrodes. The impedance channels were located 5, 7, 9, 11, 13, and $15 \mathrm{~cm}$ (MII7-MII2) from the distal tip in the esophagus in the smaller catheter and 3, 5, 7, 9, 15, and $17 \mathrm{~cm}$ (MII7-MII2) in the larger catheter. The length of the impedance probe was estimated in each case to match the child's height on the basis of special charts. ${ }^{9}$ Before the procedure, the $\mathrm{pH}$ sensors were calibrated using buffered solutions of $\mathrm{pH} 4$ and 7. The probe was introduced through the nose to the esophagus under local anesthesia, after fasting for at least 4-6 hours. The catheter was placed using a UES manometric localizer (Air Flow; Sandhill Scientific Inc) so that the upper pH sensor (MII1) was situated $1 \mathrm{~cm}$ above the upper edge of the UES, and the lower $\mathrm{pH}$ sensor (MII8) was positioned 3-5 cm above the lower esophageal 


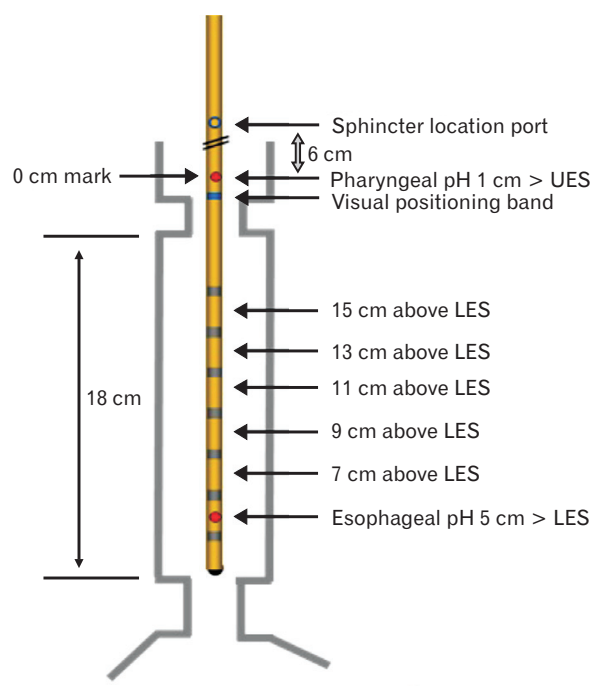

Figure 1. Scheme of the impedance probe used in the study. UES, upper esophageal sphincter; LES, lower esophageal sphincter.

sphincter. A chest X-ray was additionally taken to confirm proper positioning of the probe. The data provided by the probe with a frequency of $50 \mathrm{~Hz}$ were recorded over a 24-hour period. The patients were encouraged to maintain normal activity, sleep schedules, and eat their usual meals at their normal times. The scheme of the $\mathrm{MII} / \mathrm{pH}$ probe is shown in Figure 1.

According to the MII changes, GER events were classified as liquid, gas, or mixed. Liquid episodes were defined as a retrograde drop in at least 2 consecutive distal impedance channels to $\leq 50 \%$ of the baseline, and gas episodes were defined as a rapid increase in impedance $>3000 \Omega$. Mixed episodes were defined as gas reflux occurring during or immediately before a liquid reflux. If the bolus reached one or both of the 2 most proximal impedance channels, the reflux was defined as proximal.

According to the corresponding $\mathrm{pH}$ changes in the lower $\mathrm{pH}$ sensor, the GER episodes were classified as acid $(\mathrm{pH}<4)$ and non-acid ( $\mathrm{pH} \geq 4)$.

The evaluated parameters in $\mathrm{pH}$ monitoring were: reflux index (RI) in the upright and RI in the recumbent positions, number of GER episodes according to $\mathrm{pH}$ monitoring, number of GER episodes $>5$ minutes, duration of the longest GER episode, and DeMeester score. ${ }^{10}$ Pathological acid GER was diagnosed if the acid exposure percent time (AEPT) in the lower $\mathrm{pH}$ sensor was $>4.2$, if the DeMeester score was $>14.7$ or if the acid bolus exposure percent time (BEPT) was $>1$ 1.1. Pathological non-acid GER was diagnosed if the total BEPT was greater than 1.4 and, simultaneously, no acid reflux was found.
We defined pathological LPR as at least one episode of $\mathrm{pH}$ $<5$ in the upper $\mathrm{pH}$ sensor with a drop of $\mathrm{pH}$ equal to or greater than 0.2 ("delta" $\mathrm{pH} \geq 0.2$ ) compared to the initial value during the 24-hour $\mathrm{MII} / \mathrm{pH}$ monitoring. The division of the LPR episodes as acid $(\mathrm{pH}<4)$, weakly acidic $(4 \leq \mathrm{pH}<7)$, and weakly alkaline $(\mathrm{pH} \geq 7)$ was made on the basis of the measurement of the pharyngeal $\mathrm{pH}$ sensor.

Additionally, we formulated our own criteria as follows to diagnose LPR episodes using this type of dual-probe $\mathrm{MII} / \mathrm{pH}$ catheter with the upper $\mathrm{pH}$ sensor localized above the UES:

(1) The LPR episode was preceded by a retrograde bolus movement in all 6 impedance channels in the esophagus.

(2) The bolus reached the pharynx if there was an impedance change in the most proximal MII channel with a simultaneous or subsequent $\mathrm{pH}$ drop of at least 0.2 in the upper $\mathrm{pH}$ ("delta" $\mathrm{pH} \geq 0.2$ ) sensor.

The $\mathrm{pH}$ change observed in the upper $\mathrm{pH}$ sensor must be preceded by a $\mathrm{pH}$ change in the lower $\mathrm{pH}$ sensor and must be correlated to the retrograde bolus movement detected by MII. The amplitude of the $\mathrm{pH}$ change in the pharyngeal $\mathrm{pH}$ sensor must be equal to or lower than that in the esophageal $\mathrm{pH}$ sensor, while the $\mathrm{pH}$ value in the pharyngeal $\mathrm{pH}$ sensor must be equal to or greater than that in the esophageal $\mathrm{pH}$ sensor. All of the above enlisted criteria must be fulfilled to diagnose an LPR episode.

Analysis of the 24-hour MII/pH recordings was performed automatically, and in all of the patients it was subsequently followed by a manual analysis carried out by a single observer using a dedicated software program (Sandhill Scientific Inc). In case of uncertainty, another expert observer was consulted.

\section{Results}

Twenty-two children (79\%) had bilateral and 6 (21\%) had unilateral OME. The effusion was found in 23 cases in the right ear and in 27 cases in the left ear. The mean air bone gap was $26.4 \mathrm{~dB}$ (range 7.5-60 dB) in the right ear and $25.7 \mathrm{~dB}$ (range 7.5-42.5 dB) in the left ear. Tympanogram type B was noted in 44 ears and type $\mathrm{C} 2$ in 6 ears.

Gastroesophageal symptoms were reported by 16 (57\%) patients (Fig. 2). Extraesophageal complaints were noted in $20(71 \%)$ children (Fig. 3). Both gastroenterological and extraesophageal symptoms were noted in $15(53.5 \%)$ children, and 7 (25\%) patients reported no symptoms at all.

LPR was diagnosed in 19 (67.9\%) patients. In total, 64 LPR episodes were detected: $89 \%$ were in the upright position; 26 (46\%) 
were liquid; 23 (40\%) were mixed, and 8 (14\%) were gaseous. In the recumbent position, no gas episodes were observed; 6 (86\%) were liquid and 1 (14\%) was mixed.

Assuming more stringent criteria for LPR, with $\mathrm{pH}$ in the upper sensor below 5.0 and "delta" $\mathrm{pH} \geq 1.0$, in total there were 21 (39.28\%) episodes; with $\mathrm{pH}<4.0$ and "delta" $\mathrm{pH} \geq 1.0,9$ (28.57\%) LPR episodes were observed in 8 children.

Evaluating the $\mathrm{MII} / \mathrm{pH}$ recordings using our own definition

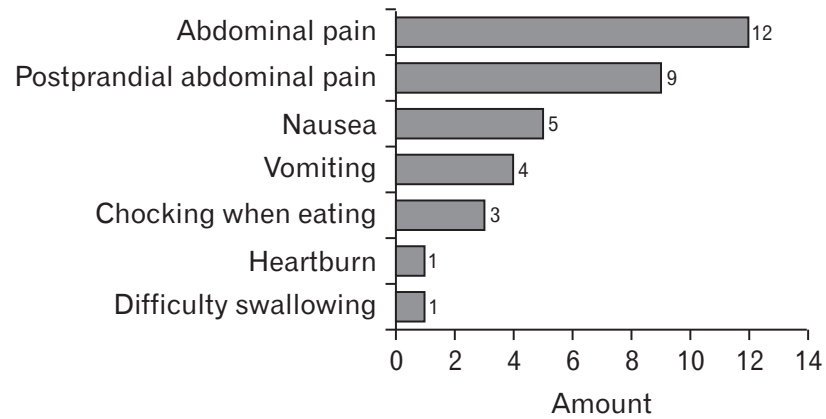

Figure 2. The gastroesophageal symptoms $(n=28)$.

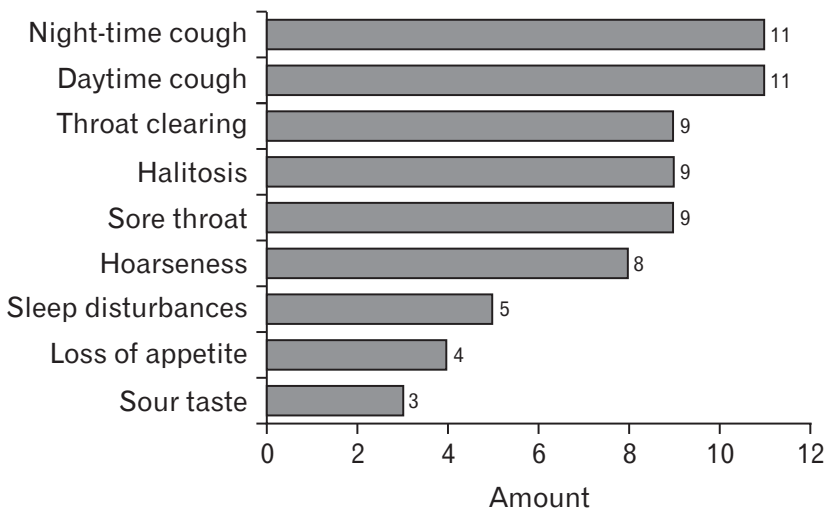

Figure 3. The extraesophageal symptoms $(\mathrm{n}=28)$. of LPR episode, 246 episodes were detected; 216 (87.8\%) were weakly acidic, 16 (6.5\%) were acid, and 14 (5.7\%) were weakly alkaline (Fig. 4). Among 215 (87\%) LPR episodes noted in the upright position, 88 (35.7\%) were liquid, 84 (34.1\%) were mixed, and $74(30 \%)$ were gas. In the recumbent position, liquid reflux predominated $(87 \%)$.

The total number of GER episodes was 1732, of which 1372 (79.2\%) were proximal; $246(17.9 \%)$ of the proximal episodes exceeded UES and became LPR episodes (Table 1). The mean AEPT in our study group was $2.4 \% \pm 1.97$; in the LPR positive $(\mathrm{LPR}+)$ group, it was $3.04 \% \pm 2.01$, and in the LPR negative (LPR-) group, it was $0.94 \% \pm 0.76$. The mean number of reflux events was $61.9 \pm 21.95$, and this result did not differ significantly between the LPR+ and the LPR- groups (63.6 \pm 20.6 and 58.2 \pm 25.93 , respectively). Eight hundred and ninety-four (52.4\%) GER episodes were acid and 812 (47.6\%) were non-acidic.

Pathological (acid and non-acid) GER was noted in 10 (35.7\%) subjects. Acid GER was diagnosed in $8(28.6 \%)$ patients, whereas

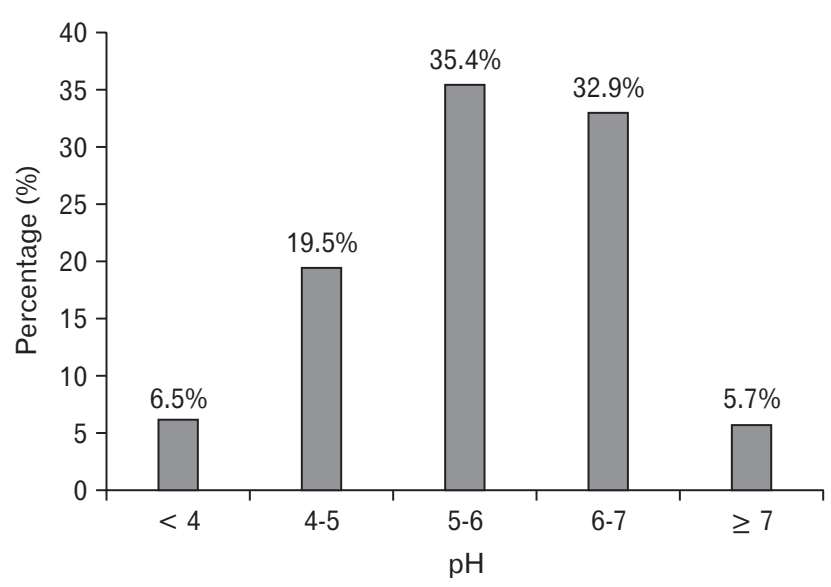

Figure 4. Percentage of laryngopharyngeal reflux episodes according to $\mathrm{pH}(\mathrm{n}=246)$.

Table 1. Distribution of the Number of All Gastroesophageal Reflux Episodes According to Their Extent in the Esophagus and Chemical Properties $(\mathrm{N}=1732)$

\begin{tabular}{|c|c|c|c|c|c|c|}
\hline \multirow{2}{*}{ GER episodes } & \multirow{2}{*}{$\begin{array}{l}\text { Total number of episodes } \\
\text { (median per patient } \\
\text { [first quartile-third quartile]) }\end{array}$} & \multirow{2}{*}{$\begin{array}{c}\begin{array}{c}\text { Proximal esophagus } \\
\text { (number of episodes) }\end{array} \\
\text { MII2 }\end{array}$} & \multicolumn{3}{|c|}{$\begin{array}{l}\text { Middle esophagus } \\
\text { (number of episodes) }\end{array}$} & \multirow{2}{*}{$\begin{array}{c}\begin{array}{c}\text { Distal esophagus } \\
\text { (number of episodes) }\end{array} \\
\text { MII6 }\end{array}$} \\
\hline & & & MII3 & MII4 & MII5 & \\
\hline Total & $1732(59.5[49.5-71.3])$ & 1372 & 1490 & 1554 & 1664 & 1732 \\
\hline Liquid episodes & $780(24.0[16.5-37.0])$ & 454 & 563 & 621 & 719 & 780 \\
\hline Gas episodes & $498(9.5[5.8-30.5])$ & 466 & 475 & 481 & 491 & 498 \\
\hline Mixed episodes & $454(14.0[8.8-22.0])$ & 452 & 452 & 452 & 454 & 454 \\
\hline
\end{tabular}

GER, gastroesophageal reflux. 
2 children demonstrated non-acidic reflux. GER was diagnosed in $50 \%$ of the patients with LPR (the criteria of LPR pH $<5$, the "delta" $\mathrm{pH} \geq 0.2$ ). In the LPR-negative patients, only 1 case of a non-acidic reflux was found (Fig. 5).

The LPR occurrence in boys and girls was similar; however, gaseous episodes were significantly more frequent in girls $(P=$

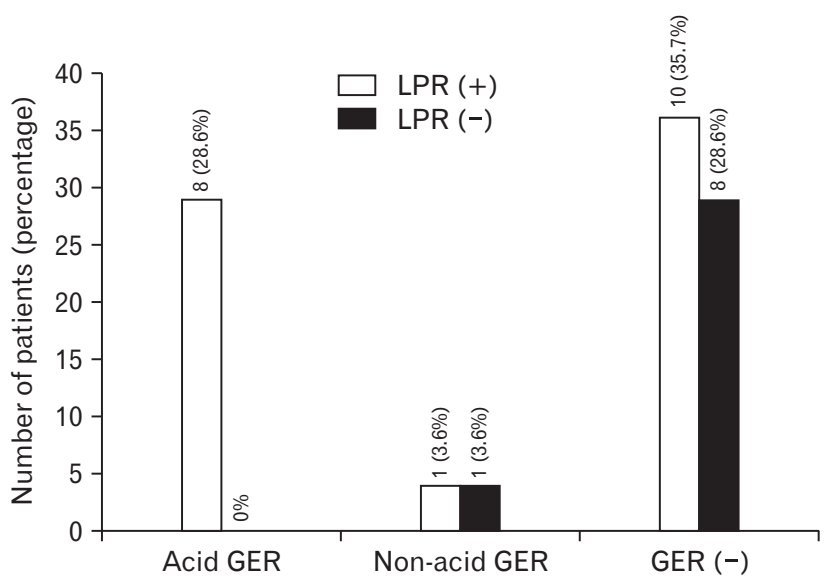

Figure 5. Percentage of patients diagnosed with gastroesophageal reflux (GER) in the group of patients with laryngopharyngeal reflux positive $(\mathrm{LPR}+)$ and the $\mathrm{LPR}-$ (the criteria of $\mathrm{LPR} \mathrm{pH}<5$, the "delta" $\mathrm{pH} \geq 0.2)(\mathrm{n}=28)$.
0.019). The characteristics of MII recording in the LPR+ and LPR- group of patients are shown in Table 2 .

There was no difference in the LPR occurrence using the criteria of $\mathrm{pH}<5$, delta 0.2 between children with bilateral and unilateral OME. Applying our own criteria, LPR episodes were more frequent ( 9 episodes per person [quartile $5.25 ; 12.0$ ] in the group of patients with bilateral OM, and 5 episodes per person in children with unilateral OME [quartile $4.25 ; 5.0]$ ), but it was not statistically significant $(P=0.081)$.

\section{Discussion}

The present study was designed to characterize LPR and GER in children with OME with the use of 24-hour multichannel esophageal impedance combined with dual-probe $\mathrm{pH}$ monitoring. This is the first paper describing the appliance of such a catheter with an upper $\mathrm{pH}$ probe localized above the UES in the lower part of the pharynx in children. Because there is no LPR definition with the use of this type of $\mathrm{MII} / \mathrm{pH}$ catheter, we decided to set the definition based on our own observations.

We describe an LPR episode when a pH change in the upper $\mathrm{pH}$ sensor was noticed just after bolus movement reached the highest $\mathrm{MII}$ ring. We decided to set the minimum change in $\mathrm{pH}$ for 0.2 ("delta" $\mathrm{pH} \geq 0.2$ ). Such a value has also been used by other

Table 2. Comparison of the Characteristics of Reflux Between Patients with Laryngopharyngeal Reflux and Without Proven Laryngopharyngeal Reflux (the Criteria of LPR pH $<5$, the "Delta" $\mathrm{pH} \geq 0.2)(\mathrm{n}=28)$

\begin{tabular}{|c|c|c|c|}
\hline Characteristics & $\begin{array}{l}\text { LPR+ } \\
(n=19)\end{array}$ & $\begin{array}{c}\text { LPR- } \\
(n=9)\end{array}$ & $P$-value \\
\hline Age $($ mean $\pm \mathrm{SD}, \mathrm{yr})$ & $7.3 \pm 1.18$ & $7.4 \pm 0.59$ & 0.312 \\
\hline Boys (n $[\%])$ & $11(58)$ & $6(67)$ & 0.000 \\
\hline \multicolumn{4}{|c|}{ Number of episodes (median per patient [first-third quartile]) } \\
\hline GER (all episodes) & $60.00[50.50-70.50]$ & $59.00[48.00-81.00]$ & 0.787 \\
\hline Gas & $9.00[3.50-18.00]$ & $22.00[9.00-35.00]$ & 0.065 \\
\hline Liquid & $29.00[18.00-37.50]$ & $21.00[15.00-25.00]$ & 0.325 \\
\hline Mixed & $20.00[13.50-26.50]$ & $9.00[5.00-13.00]$ & 0.010 \\
\hline Proximal GER episodes & $52.00[43.50-55.50]$ & $47.00[34.00-65.00]$ & 0.640 \\
\hline \multicolumn{4}{|c|}{ Clearance (median per patient [first-third quartile], sec) } \\
\hline Median BCT & $11.00[9.50-16.50]$ & $10.00[8.00-13.00]$ & 0.311 \\
\hline Proximal BCT & $10.63[7.49-17.96]$ & $11.34[8.04-16.73]$ & 0.883 \\
\hline Lower ACT & $86.00[49.00-104.50]$ & $58.00[40.00-71.00]$ & 0.085 \\
\hline Upper ACT & $0.40[0.00-6.70]$ & $0.00[0.00-0.00]$ & 0.006 \\
\hline \multicolumn{4}{|c|}{ Percent time (median per patient [first-third quartile], \%) } \\
\hline AEPT & $2.70[1.65-4.65]$ & $0.70[0.40-1.30]$ & 0.006 \\
\hline BEPT & $1.30[0.85-1.85]$ & $0.60[0.50-0.70]$ & 0.013 \\
\hline
\end{tabular}

$\mathrm{LPR}+$, laryngopharyngeal reflux positive group; LPR-, laryngopharyngeal reflux negative group GER, gastroesophageal reflux; BCT, bolus clearance time; ACT, acid clearance time; AEPT, acid exposure percent time; BEPT, bolus exposure percent time. 
authors. $^{11}$

In this paper, we recognize clinically significant LPR on the basis of a $\mathrm{pH}$ drop $<5.0$ in the upper sensor. This criterion is supported by studies on pepsin activity and its influence on the upper respiratory tract mucosa. ${ }^{12}$ Pepsinogen is activated at a $\mathrm{pH}$ below 4.0 and forms pepsin. Pepsin remains active up to $\mathrm{pH}$ 6.5. Then, it is inactivated but is still stable and can be reactivated if the $\mathrm{pH}$ drops. ${ }^{12}$ The most recent studies show that pepsin can also be reactivated within the acidic intracellular environment after receptormediated uptake of pepsin by laryngeal epithelial cells, even if the $\mathrm{pH}$ in the throat is up to $7.4 .^{13}$

Moreover, the epithelial cells of the throat are susceptible to pepsin even in a non-acidic environment because pepsin stimulates the expression of many proinflammatory cytokines and receptors, such as CCL20, CCL26, IL8, IL1F10, IL1A, Il5, BCL6, CCR6, and $\mathrm{CXCL} 14{ }^{14}$

In previous papers, particularly when only $\mathrm{pH}$ monitoring was performed, LPR was diagnosed if there was at least one episode of a $\mathrm{pH}$ drop in the proximal sensor below $4.0^{4}$ or $5.0,{ }^{12,15}$ along with a "delta" $\mathrm{pH}>1.0{ }^{4}$ In the present study, we detected 9 episodes of $\mathrm{LPR}$ by applying the criteria $\mathrm{pH}<4.0$ and "delta" $\mathrm{pH} \geq 1.0$, or 21 episodes of LPR by applying the criteria $\mathrm{pH}<5.0$, "delta" $\mathrm{pH}$ $\geq 1.0$, or 64 episodes of LPR with the criteria $\mathrm{pH}<5.0$, "delta" $\mathrm{pH} \geq 0.2$.

Chiou et $\mathrm{al}^{16}$ used classic $\mathrm{pH}$ monitoring with a dual $\mathrm{pH}$ sensor (pharyngeal and esophageal) in a group of 32 children. The authors used $3 \mathrm{pH}$ thresholds for LPR episode. Apart from the classic $\mathrm{pH}$ value below 4.0 they set a second $\mathrm{pH}$ threshold below 5.5 in the upright position and below 5.0 in the recumbent position and the third cut of value if the $\mathrm{pH}$ dropped more than $10 \%$ in relation to the baseline. Chiou et $\mathrm{al}^{16}$ observed 200 LPR episodes when applying the criterion of $\mathrm{pH}$ below 4.0 and 295 and 301 LPR episodes using the second and third criteria, respectively. The more liberal the criteria, the more LPR episodes were observed. We obtained similar results; however, we noted fewer LPR episodes than Chiou et $\mathrm{al}^{16}$ because we recorded only $\mathrm{pH}$ drops preceded by an impedance change.

There are no pediatric studies with which to compare our results. In adult studies, the number of LPR episodes was higher than we observed. In total, Kawamura et $\mathrm{al}^{11}$ recorded more than 700 LPR episodes in 30 adults using a specially designed catheter with two MII rings and a $\mathrm{pH}$ probe localized above the UES. In another study, the same author noted a total of 566 LPR episodes in 31 adults. ${ }^{17}$ In the group with chronic laryngitis, there were 11.5 LPR episodes per person.
In the studies carried out on healthy adult volunteers, the number of LPR episodes varied from 51 in 10 volunteers ${ }^{18}$ to 6 in 8 volunteers. ${ }^{19}$ Both authors used a bifurcated $\mathrm{MII} / \mathrm{pH}$ catheter with a dual $\mathrm{pH}$ probe. In total, in the present study, we observed 246 LPR episodes: 8.8 episodes per child. These discrepancies might result from a different methodology and different age groups.

Assessing the physical properties of the LPR, we observed $35.7 \%$ liquid, $34.14 \%$ mixed, and $30 \%$ gaseous episodes in total. In the recumbent position, the majority of the episodes were liquid $(87 \%)$. Kawamura et $\mathrm{al}^{11}$ had similar observations: $46 \%$ liquid, $43 \%$ mixed, and $10 \%$ gaseous events.

In the present study, we diagnosed 216 weakly acidic LPR episodes. In the distal esophagus, $65 \%$ of these episodes were acidic and $35 \%$ were weakly acidic. Kawamura et $\mathrm{al}^{17}$ and Oelschlager et $\mathrm{a}^{18}$ had similar observations. A primary acid GER episode is slightly alkalized before it reaches the lower part of the throat, which results in a weakly acidic LPR.

In previous studies conducted in children with OME, only the $\mathrm{pH}$ was measured (single or dual $\mathrm{pH}$ probe). ${ }^{20-23} \mathrm{Abd}$ El-Fattah et $\mathrm{al}^{20}$ used dual $\mathrm{pH}$ monitoring with the upper $\mathrm{pH}$ probe $1 \mathrm{~cm}$ above the UES. In a group of 31 children with OME, they diagnosed GER in 6 patients and LPR in $71 \%$ of the patients using the cutoff value of $\mathrm{pH}<4.0$. With the $\mathrm{pH}$ threshold $<5.0$ in the lower throat, the percentage of the patients diagnosed with LPR increased to $87.1 \%$.

In a second study, Rozmanic et $\mathrm{al}^{21}$ applied a dual $\mathrm{pH}$ catheter with an upper $\mathrm{pH}$ probe in 11 children with OME, and recognized LPR in 3 children and GER in 6 children. Keles et $\mathrm{al}^{22} \mathrm{ex}-$ amined children with $\mathrm{OME}$ using a dual $\mathrm{pH}$ probe with an upper $\mathrm{pH}$ sensor in the proximal esophagus. Other authors have applied a single $\mathrm{pH}$ sensor in the distal esophagus. ${ }^{23}$ It is generally impossible to predict LPR on the basis of a $\mathrm{pH}$ drop in the distal or proximal esophagus and this might lead to the misdiagnosis of LPR.

The absence of MII rings in the throat limits the methodology of the present study, but at the time of the planning of the present study, there were no $\mathrm{MII} / \mathrm{pH}$ catheters with MII rings above the UES designed for children. We are convinced that more studies using a similar $\mathrm{MII} / \mathrm{pH}$ catheter with an upper $\mathrm{pH}$ sensor placed above the UES are needed.

LPR was frequently noted in the group of children with OME, and it might be an important risk factor in this common disease.

Acknowledgements: The work was done in the Department of Otolaryngology, Rydygier Memorial Specialistic Hospital and 
the Department of Pediatrics, Gastroenterology and Nutrition, Collegium Medicum Jagiellonian University, Cracow, Poland. The authors thank Małgorzata Sładek (Department of Pediatrics, Gastroenterology and Nutrition, Collegium Medicum Jagiellonian University, Cracow, Poland) for help in designing the study and experience in evaluation of $\mathrm{MII} / \mathrm{pH}$-metry. We also thank Kamil Fijorek (Department of Statistics, Cracow University of Economics) for statistical calculations.

\section{Financial support: None.}

\section{Conflicts of interest: None.}

Author contributions: Anna Górecka-Tuteja designed and performed experiments, collected, interpreted and analyzed data, and drafted the article; Izabela Jastrzębska designed and performed experiments, collected, interpreted, and analyzed data, and drafted the article; Jacek Składzień designed experiments and provided critical revision; and Krzysztof Fyderek designed and performed experiments, provided critical revision, and made final approval of the version to be published.

\section{References}

1. American Academy of Family Physicians; American Academy of Otolaryngology-Head and Neck Surgery; American Academy of Pediatrics Subcommittee on Otitis Media With Effusion. Otitis media with effusion. Pediatrics 2004;113:1412-1429.

2. Blustone CD, Klein JO. Otitis media in infants and children. 2nd ed. Philadelphia: Saunders 1995:17-37.

3. Thomsen J, Tos M. Spontaneous improvement of secretory otitis media. Acta Otolaryngol 1981;92:493-499.

4. Koufman JA. The otolaryngologic manifestations of gastroesophageal reflux disease (GERD): a clinical investigation of 225 patients using ambulatory 24-hour $\mathrm{pH}$ monitoring and an experimental investigation of the role of acid and pepsin in the development of laryngeal injury. Laryngoscope 1991;101(4 Pt 2 suppl 53):1-78.

5. Yilmaz MD, Aktepe O, Cetinkol Y, Altuntaş A. Does Helicobacter pylori have role in development of otitis media with effusion? Int J Pediatr Otorhinolaryngol 2005;69:745-749.

6. Vakil N, van Zanten SV, Kahrilas P, Dent J, Jones R; Global Consensus Group. The Montreal definition and classification of gastroesophageal reflux disease: a global evidence-based consensus. Am J Gastroenterol 2006;101:1900-1920.

7. Sherman PM, Hassall E, Fagundes-Neto U, et al. A global, evidencebased consensus on the definition of gastroesophageal reflux disease in the pediatric population. Am J Gastroenterol 2009;104:1278-1295.

8. Deal L, Gold BD, Gremse DA, et al. Age-specific questionnaires dis- tinguish GERD symptom frequency and severity in infants and young children: development and initial validation. J Pediatr Gastroenterol Nutr 2005;41:178-185.

9. Yang GS, Bishop WP, Smith BJ, Goudy SL, Sato Y, Bauman NM. Radiographic and endoscopic measurements of esophageal length in pediatric patients. Ann Otol Rhinol Laryngol 2005;114:587-592.

10. DeMeester TR, Wang CI, Wernly JA, et al. Technique, indications, and clinical use of 24 hour esophageal $\mathrm{pH}$ monitoring. J Thorac Cardiovasc Surg 1980;79:656-670.

11. Kawamura O, Shimoyama Y, Hosaka H, et al. Increase of weakly acidic gas esophagopharyngeal reflux (EPR) and swallowing-induced acidic/ weakly acidic EPR in patients with chronic cough responding to proton pump inhibitors. Neurogastroenterol Motil 2011;23:411-418, e172.

12. Johnston N, Dettmar PW, Bishwokarma B, Lively MO, Koufman JA. Activity/stability of human pepsin: implications for reflux attributed laryngeal disease. Laryngoscope 2007;117:1036-1039.

13. Johnston N, Wells CW, Samuels TL, Blumin JH. Pepsin in nonacidic refluxate can damage hypopharyngeal epithelial cells. Ann Otol Rhinol Laryngol 2009;118:677-685.

14. Samuels TL, Johnston N. Pepsin as a causal agent of inflammation during nonacidic reflux. Otolaryngol Head Neck Surg 2009;141:559-563.

15. Postma GN. Ambulatory pH monitoring methodology. Ann Otol Rhinol Laryngol Suppl 2000;184:10-14.

16. Chiou E, Rosen R, Nurko S. Effect of different $\mathrm{pH}$ criteria on dualsensor $\mathrm{pH}$ monitoring in the evaluation of supraesophageal gastric reflux in children. J Pediatr Gastroenterol Nutr 2011;52:399-403.

17. Kawamura O, Aslam M, Rittmann T, Hofmann C, Shaker R. Physical and $\mathrm{pH}$ properties of gastroesophagopharyngeal refluxate: a 24-hour simultaneous ambulatory impedance and $\mathrm{pH}$ monitoring study. Am J Gastroenterol 2004;99:1000-1010.

18. Oelschlager BK, Quiroga E, Isch JA, Cuenca-Abente F. Gastroesophageal and pharyngeal reflux detection using impedance and 24-hour $\mathrm{pH}$ monitoring in asymptomatic subjects: defining the normal envirement. J Gastrointest Surg 2006;10:54-62.

19. Wang AJ, Liang MJ, Jiang AY, et al. Gastroesophageal and laryngopharyngeal reflux detected by 24-hour combined impedance and $\mathrm{pH}$ monitoring in healthy Chinese volunteers. J Dig Dis 2011;12:173-180.

20. Abd El-Fattah AM, Abdul Maksoud GA, Ramadan AS, Abdalla AF, Abdel Aziz MM. Pepsin assay: a marker for reflux in pediatric glue ear. Otolaryngol Head Neck Surg 2007;136:464-470.

21. Rozmanic V, Velepic M, Ahel V, Bonifacic D, Velepic M. Prolonged esophageal $\mathrm{pH}$ monitoring in the evaluation of gastroesophageal reflux in children with chronic tubotympanal disorders. J Pediatr Gastroenterol Nutr 2002;34:278-280.

22. Keleş B, Oztürk K, Günel E, Arbağ H, Ozer B. Pharyngeal reflux in children with chronic otitis media with effusion. Acta Otolaryngol 2004;124:1178-1181.

23. Velepic M, Rozmanic V, Velepic M, Bonifacic M. Gastroesophageal reflux, allergy and chronic tubotympanal disorders in children. Int J Ped Otorhinolaryngol 2000;55:187-190. 